\title{
Research: Philosophy Intercultural
}

\author{
Kuang-Ming Wu \\ University of Wisconsin-Oshkosh, Oshkosh, WI, USA \\ Email: kmwu2002@yahoo.com
}

Received 19 May 2014; revised 25 June 2014; accepted 8 July 2014

Copyright (C) 2014 by author and Scientific Research Publishing Inc.

This work is licensed under the Creative Commons Attribution International License (CC BY).

http://creativecommons.org/licenses/by/4.0/

(c) (i) Open Access

\begin{abstract}
Research is our radical search-around in all directions imaginable. It inevitably turns to self-scrutinize to self-direct toward comprehensive interculture, as interaction of many modes of thinking and searching, even methodologically on how research goes. This Socratic-comprehensive turn of research is philosophy, research of all researches. This essay common-sensibly elucidates their triune intimacy, from research via philosophy to interculture. Thus this essay has three parts, A: research, B: philosophy, and C: interculture. Part A researches into why, what, and how of research, and then explores its Janus-faced door. Part B reflects on what was explained on research as philosophy, as catalyst of research to interculture. Part $C, 1)$ looks at two contrastive cultures, the West and China as typical of "many world cultures," 2) how the West and China interculture, to conclude with two cautions on interculture in our research.
\end{abstract}

\section{Keywords}

Research, Philosophy, Interculture

\section{Introduction}

Research is our search-around in all directions imaginable. It inevitably turns to self-scrutinize to self-direct toward comprehensive interculture as interacting varied thinking-modes searching, methodologically on how research goes fittingly, a Socratic turn of research as philosophy, research of all researches. This essay unpacks the triune intimacy, from research via philosophy to interculture, in common sense. To cite a simple trivial example not simple trivial—nothing is simple trivial_-we play peekaboo with a baby giggling at it; we giggle, too. We know how the baby is delighted with the surprise and we are not, yet we continue it. We may then ask why we giggle at what we are not surprised, and answer we enjoy being with an innocent baby; and then why being-with is delightful is now a delightful theme. Human sociality has long been prominently featured in Aristotle, Heidegger, Buber, Huizinga, Wach, Levinas, Wu, and countless others (Levinas \& Lingis, 1969; Wu, 2008). We dig into why sociality ubiquitous- “peekaboo” enjoyed everywhere-is joy, why it is a joy to dig into social joy. 
"Hide and seek" more complex can be researched in the same way.

"Why do we continue to do peekaboo we don’t enjoy on the baby enjoying it?” The question persists. Another reason besides our joy of being with the baby, a part of sociality, may be that the baby gives us joy-at-surprises we lack, and we must have that joy to live vigorously, as the baby does. Peekaboo shows sudden unexpected appearance and disappearance, suggesting sudden unexpected appearance and disappearance of reality! Such real suddenness is really surprising, quite earth-shaking!

And we partake of this baby-revolution of the world, with this baby-joy so fresh. All this is common sense so surprising, fresh as the baby. Common sense is culture; common sense ubiquitous shows interculture. Philosophy researches in commonsense interculture. Trinitarian intimacy of research, philosophy, and interculture is waiting for this essay to dig into.

Thus this essay has three parts, A: research, B: philosophy, and C: interculture. Part A researches into why, what, and how of research, and then explores its fascinatingly complex nature as a Janus-faced door. Part B reflects on research as philosophy a catalyst to interculture. Part C looks at 1) two contrasting cultures, the West and China, typical "world cultures," and 2) how both do interculture, to conclude with two cautions on interculture in research.

\section{Part A: Research}

We humans live research to grow in research; as birds are born to sing, so we must research to live as human. Seeking why research, what research, and how research, as here, is part of research. Such statements seeming bold can be explained as quite natural by plunging into why, what, and how of research.

Why must we do research? We need research as we must grow to be human; stopping growing stops humanly alive. We grow in wonder, Aristotle said without explaining wonder. Wondering, we search for things new to grow beyond us, to grow human. No transcendence is no-growth, and humanity vanishes. We grow by searching novelty, researching; humanity by nature does research beyond here now.

What is research, then? Research is searching-around, deep and wide. Its depth is a radical digging; its width is comprehensive ubiquity in interculture. Interestingly, in research, its goal is its method. Ubiquity-as-goal is comprehensiveness-as-method; interculture is goal and method of research; root-of-things as goal of research is "going to the final bottom of the matter" as its method. Research-how as goal is research-what, in intercultural ubiquity digging to the root.

Ubiquity is concrete inter-locality toward global interculture. This is research's goal, to be validated intercultural. Ubiquity comprehensively covers areas for research; this is research's method. Research continually digs into the matter to reach its rock-bottom. Ubiquity and depth are goal and method of research. But the "root" of interculture is bottomless, incarnated here now among children freely playing with kids of all cultures. Kids are all playmates, never enemies who cannot play.

“Can research reach certainty, though?” Two points are here. One, research is human pursuit, while the researched is no part of pursuit. Caution stems from this fact, and caution rejects cocksure affirmation or denial of the validity of research. Since what is found true may be false, research focuses not on pursuing uncertain truth but on learning from what is found "false." Learning from falsehood assures of progress.

"Science makes progress," we say; science steps (-gress) ahead (pro-). "Is it sure it is not stepping-back, backsliding?” Well, science is proverbially cautious on everything, including itself. Self-caution self-examines. If the first examined (e-1) result is found by the next one (e-2) to have erred, e-2 would find things to learn from what e-1 judged as “false," and "learning” is a step ahead, a progress.

An occasional backsliding found by later examination always occasions later learning to step ahead; backsliding begins progress. Thus, cautiously, science-knowing-process-does make progress. In fact, this is how kids happily learn from fun-“mistakes” to make progress. Kids enjoy "funny” irregularities of mistakes, to enjoy learning to forward out of them. So, kids are also "cautious," self-critical to self-progress (Wu, 2008). Childhood certainty is childhood enjoyment of learning from mistakes.

Two, thus research certainty lives in Paradise beyond life (to tie up this essay to end it); kids frolic in it devilmay-care, in certainty they couldn’t care less! “What's your name?” “I don’ kno’; Mom kno’!” Wow! That’s certainty in simplicity! "Simple” attains “certain.” Research reaches home to our child-certainty. "But we are kids no more; how do we attain child-certainty?” It is a good tough question connected with point two here. We must try (research) without trying, as kids (backward research!). "But how can we do backward research?” That 
invincible "Mom kno'!" child tells us that "simple” attains "certain.” Searching child-certainty parallels attaining (not achieving) the artless art of simplicity. Gregorian Chants are so simple so soothing calming that, even though their CDs last only 50 odd minutes each, they go so rich so infinite (Apel, 1972)! Beauty is simple, but simplicity can be ugly brutality, and why it can be so is mysterious beyond me. Simplicity is infinity! And infinity is right here in sheer simplicity.

The see-through simplicity of medieval carols and chants simply disarms us at home, in us invisible bottomless. I know I said it before, but I cannot help but say it again, for it is just so alluring, as one's self is irresistible. This simplicity is the strange power of children disarming us. This is the kid-power of not-trying. Children never try, as no one tries to live as one is. Children alone live authentically, by not-trying.

Trying only turns artificial, not simple. Simplicity arrives in daily reduction (日損 Lao Tzu 48) of conscious trials, an odd trial at reducing trying, but artists do so constantly, as in Gregorian Chants; artists arrive at children! After all, childhood is deep in us, and touted by children everyday; that is why we can love the kids and play with them. In fact we so naturally love children that we even can claim that those who hate children hate themselves. We just come home to kids, though "just” is tough! It is not simple to be simple.

The easiest we can do to reduce our days is to unclutter unneeded complexity. We kick off our shoes and socks, take off our coat, drink some water, and take a deep breath. Now we have just simplified ourselves; it is powerful. Simplicity packs to pierce, in kid-delight. Such kid-innocence has wit, satire, humor, all profoundly alive. Alive is simple, afresh, piercing to the basics, quite infinite. Research reaches here. Now let us look at "research" itself. Research is search-around, as its etymology says. "Research (XIII: 693)" is "re-(XIII: 247251)" combined with "search, to surround in circle (XIV: 805)" (Oxford English Dictionary, 2001); it is a constantly changing Janus-door. "Janus" is free-standing doorway, the beginning, the double-faced god of all gods (Howatson, 1991: p. 304). Things must change lest they rot and die, and rot-die is also change. Science-research-must change, even shifting its very paradigm (Kuhn, 1962). This revolution is scientific progress. It happens by self-caution, Socratic self-scrutiny. Caution originates in the fact that science (knowing process) is man-made, physical universe is not man-made. Caution rejects dogmatic affirmation and denial of validity of science. This self-research is another entrance of our Janus-door.

Philosophy on science is a Janus that opens it out to explore the world as it opens it in to self-examine, opening science man-made to progress by poetry man-felt embracing it. The Greek myth of Oedipus is not factual but man-spun, as science judges so, yet it is "factual" as exercising great impact on our life (Murphy, 2008), so much so that Freud uses it-as "Oedipus complex"-to explore human psyche. Psychology is an exciting science of life-poetry. Such is science-“research” expanding beyond on and on.

In contrast, a fool, one-track-minded, hangs on to a settled paradigm, just throwing around big words; he moves not an inch, rots, and dies. One Janus-door-self-scrutiny-reveals human hubris. The Beyond is beyond the human not-beyond. Religious fundamentalism hangs on to human doctrines not the Beyond as the Beyond itself, and hysterically rejects slightest deviation as "heresy." It is a sad comedy. It is surprisingly all over in nonreligious areas, passionately adhered to with religious fervor. One example is "scientism," a science fundamentalism.

Science fundamentalism is dogmatic certainty of validity of science, and is obsessed with knowledge of this world not trans-mundane, to cover trans-mundane, and hysterically rejects deviation in a report of experience of trans-mundane as "unscientific" and "false" (Alexander, 2012; Taylor, 2009); Such tragicomedy of "scientism" is a mortal stubborn disease contracted by so many scientists.

Research is ever initiating novelty, so it is its own door. "Who can out, not from door?" asks Confucius (6/17). Janus enters the brave new world of January, facing inside and out, self-scrutinizing as we explore the world outside, "back off a step, ocean wide, sky vast," back and forth. Life forever begins as Janus, inside and out, back and forth. Life is research Janus-faced.

Research is our life's door Janus-faced. To begin, research is the human door to enter the brave new world tomorrow. Confucius says (6/17), "Not through door, who can out?" Blake says, "To see a World in a Grain of Sand," each a door to a world (Blake, Erdman, Bloom, \& Golding, 1997; Laszlo, 1993). They point to excitements alive homo-cosmic. Countless grains of sand are countless doors to countless cultural worlds of doors, countless worlds indoors and outdoors, intercultural. So many cultures interact to elucidate research our door to tomorrow. We need this door, lest we stay put, rot “alive drunk, die dreamt” (China).

This research-door is Janus-faced in contrary directions, back and forth. Research cannot be directed, regimented, to end up being immobilized, yet it cannot be all random, arbitrary, and chaotic. Research must be 
chaotic orderly, undirected directed. Research is future-oriented based on the past; what has been is consulted to revolutionize what is to be. Back off, ocean wide, sky vast; the deeper rooted, the higher grown. Research is to the unknown, gauged by the known; warming up known points to unknown.

Now, "culture" is thinking mode of a local community; its language clues understanding a "culture" different from others. "Table" is not "desk" in English; they are the same Chinese word. Rice is "rice" in English; Chinese has two different words for raw-rice and cooked-rice. Chinese folks can understand "drops of water," but "drops of dew" is mystifying, for clearly they see "many dews." Specific inner feel of culture in language is lived relaxed, "fooled around" to take root in us, to compose human souls. Research must feel into such linguistic differences, to turn intercultural.

"Culture" is our conventional way of thinking; we breathe our culture in thinking, and "interculture" just breathes in many natural ways of thinking. Interculture is simple as breathing, and simplicity simplifies to unclutter things (Gray, 1970), to understand complex intercultural world. 1) Gray is not simple, to risk destroying the simple. 2) Heidegger sees the simple with complex thinking, not deriving the complex from the simple. 3) This wrong direction traps Heidegger struggling in "either academia or the simple." 4) Heidegger and Gray have no connection of the simple to interculture. Its last chapter, "Poets and Thinkers" (pp. 69-90), also parallels my view, except for 3 points. [a] The poetic as open perceiving is not poetry as defining insight into what is as is. [b] We must attend to being poetic, not to poets. [c] Morals cannot sever from the poetic and the philosophical. My disagreement with Heidegger are [a] and [b]; [c] is my disagreement with Gray and Plato. Simplicity is a nothing that gives. How does nothing give? Nothing gives by rooming us who naturally meet us, to find us. Senseless soft noises around are a nothing to bring us back to us. "Bringing" here is strange; silence brings by notbringing, bare nothing to allow ex-pressing self. "Nothing" is a mother-power to allow us to be.

In fact, this activity of simplicity is fun in research fooling around searching. Fun is the engine of research; no fun, no research that often fails. Failure is actually fun for children, and so kids are experts at research. Research in see-through simplicity resolves headaches by having fun; an example is here. An adult chemist Friedrich Kekule, all tired out, dozed off on a bus into a kid; he dreamed all elements of benzene stand up, joining hands to dance "ring around" into a neat benzene formula! It was the historic kid-moment of organic chemistry for the first time (Asimov, 1964); kid-simplicity resolves adult-headache. "The Ballad of East and West" in 1940, p. 233. Kipling may have thought "East" to be India (with his lifelong associations with India), but India is much closer to the West than China is far from the West.

Kid-simple loosens us into kids to look around; "around" is research intercultural. "Simple, in fun, and intercultural" are the three crucial adjectives of research induced by children. Simplicity bundles, bundling is logosact (Wu, 2001), and bundling of many sense-strands is interculture. Such is singing beauty, com-plex so simple.

All is "a rose is a rose is a rose" (Gertrude Stein), sheer presence of rose-beauty in its simplicity multi-plied; "Spring here!" is a long sigh after the long winter. All this is philosophizing in research intercultural, kid-alive. In this Part on research, philosophy inevitably appears as its part, as philosophy is sensitive research of all researches. We now go into philosophy as such.

\section{Part B: Philosophy}

Looking into research has shown philosophy and interculture, for "looking into research" is research into research that is philosophy, which is radically comprehensive to implicate interculture. Philosophy sensitizes the research situation now toward alternative ways of doing research. These alternatives thinking modes indicate different cultures; philosophy guides research into many cultural ways to enrich itself. Philosophy is thus a catalyst to interculture; philosophy as an open-ended inquiry—research—-turns intercultural, to make "research, philosophy, interculture" a set of ternary siblings.

Let me repeat this important point. To describe as above the why, what, and how of research is what research on research does. This research on research is philosophy ubiquitous. Philosophy is thinking, and culture is thinking-mode of a community; philosophy is cultural as culture is philosophical. Philosophy is basic comprehensive, self-scrutinizing self-directing to harvest "research as interculture." Philosophy is many-headed Hydra; humanity consists of cultures so many so confusing.

Fortunately, we can take as a typical illustration China at the apogee of the West; "Oh, East is East, and West is West, and never the twain shall meet, till they stand at God's great Judgment Seat," says Kipling (1970). We cannot help but respond that this august Seat is interculture today. The "twain," as far apart as east is from west, 
composes a Janus-door of research intercultural toward China this way and the West that way.

Western research is mathematical, measuring in numbers the discreet units in all areas, and such a frame applies even to areas unamenable to mathematical mode. Psychology, a peculiar invention of the West, is rife in statistical measurements of frequency of repetitions, without asking if number-units fixed discreet fit moods, feelings, sensitivity, and sentiments, all waft. Even relatively stable attitudes, insights, and inventions are hard to measure in fixed units, requiring ingenuity. Psychology journals are filled with proud ingenuities.

Sadly, "success" of mathematical ingenuity in psychological research hides its problems. Researchers overlook a sneaky suspicion, “Are these results, looking good on paper, valid?” Math is Zeus; anyone who suspects is struck with thunderbolts of Western research confidence. Psychology is cited as an example of overall "confidence” in all areas of research in the West, with uneasy fissures.

These fissures, invisible to conscious researchers but felt lurking behind their explicit research, indicate the necessity of multicultural perspectives besides math. Accurate validity must be subtler richer than math precision. Research must include other cultural modes, to turn intercultural. And “other cultures” exist everywhere, in many unsuspected places. Some examples suffice.

Common sense everywhere is one other culture, where research with laughter is one such. Children laughed around a man seeming ashamed. I asked what the matter was, and kids shouted, still pointing at him, "He said he has no headache. Ha! Ha! He has no headache!” I said, “What’s so funny? You guys don’t have headache, either, right?” Whereupon they laugh-shouted, “Ha! We have no headache. We are so funny! Ha! Ha!” This actual story has many layers of laughing implications. After all, we take life as headaches, and kids aptly laugh them away; it is worth researched into, in laughs.

Some short quips hit the spot. Mark Twain said, "People complain about the weather, and do nothing about it." Evoked, we can retort, “Because we don’t need to. Ha!” "Don’t you like the weather? Wait a minute” shocks us into thinking of life-weather. Andersen's fairy tale of “emperor with no clothes” is a joke no joke (Andersen, 2006). We laughingly understand life; it is deeper wider than logic, as life is larger than logic, to open us to the inner recesses of life. Many jokers thus pull down no-clothes officials from high silly pedestals (Zinsser, 2006). "Jokes are almighty" is a crucial research topic.

These stories are examples of story-thinking in history-thinking that composes the whole Chinese culture "literary historical 文史,” with tons of such stories, historical, counterfactual. Seemingly illogical as stories and history are, they are deeply logical as life is coherent pregnant, amply shown in world history. Thus biographies and histories irrelevant to readers' daily ongoing are popular worldwide always. I have just researched into the vast ranges of research, as "philosophy” intercultural. Two birds-interculture and research-are caught with one catalyst, philosophy research into researches, so fun!

Philosophy observes this fact. Research is always on a specific theme to spread pars pro toto. The crown tells of rulership; daily ongoing moment by moment is "life.” Studying dear Great Grandma hugging her great grand babies studies "history," i.e., specific stories. Inter-locality is ubiquity; specific researches amount to studying a specific thinking-mode, a culture, and a culture researched inevitably concerns interculture that is global ubiquitous. Philosophy tells us that research goes intercultural.

\section{Part C: Interculture}

Now let us tie up all things above into “interculture.” Both research (in Part A), and research on research, philosophy (in Part B), have shown that research is by nature intercultural in goal in method. This Part squarely looks at interculture itself, in three spontaneous sections, 1) description of the West and China, 2) their interculture inter-complementing, and 3) daunting interculture and collapse of interculture. This final negative route conveniently tightens this whole essay by considering how effectively we can do research in intercultural ways.

\subsection{The West and China}

We have a way of life, framework of growth, an idea-system of beliefs, attitudes, and general assumptions, called "culture". We have a convenient way of surveying unmanageably many cultures_-ways of thinking-by watching two contrasting cultures, the West and China. First, we watch Western way of thinking, and then watch Chinese way of thinking, in our over-familiarity with the West our nose invisible, and our unfamiliarity with China neglected so long, yet so human.

The West typically thinks in widely mathematical way, with “oddballs” Nietzsche, Kierkegaard, Voltaire, and 
Unamuno on sideline protesting, and yet they protest in the familiar "mathematical" mode of forceful articulation, still "footnotes to Plato" (Whitehead, 1978), however unwittingly. Mathematics deals with numbers, measures, structure in ratios, geometrical configurations, and their interrelations in clear rigorous articulation. Mathematics is a space-logic analytical, dividing things into atomistic units clear cut, each separate from the others. Separation makes for spatial rigor, logical, set, and unmoving. Pythagoras reduced moving music to static ratios. Parmenides radicalized logical rigor to reject motion and change.

Rigorous separatism of mathematics inevitably leads the West (in Plato) to separate clear-cut thinking from this world of change so messy, wavering, and uncertain. Plato in the end envisioned the Realm of Idea and Ideal Forms as really real, partaking of which alone makes real this changing fleeting world. Such is mathematically expected.

Even empiricist Aristotle pursued that by which all things are grasped summed in rigor in objectivity, by observing confusing jumbles of things in separative clarity logical, to end in metaphysics - thinking behind physical matters - of the unmoved mover as thinking thinking-itself, in logical "Categories," "Analytics" prior and posterior, and "Topics." Earlier thinkers aphoristic, metaphoric, evocative, poetic, naively thinking of motionchange, are excluded as "pre-Socratic" from Platonic "orthodox" philosophy.

Western thinking continues as "footnotes" to Plato who is a footnote to Pythagoras. Today's cosmologies and cosmogonies logicize space-time continuum and configuration (relativity and beyond) in mathematical formulae. Western research remains in the paradigm of logic of space, rigorous, formal, and unmoving.

Thus Western thinking is mathematical, analytically structured in number-units, in geometric configuration, formally rigorous, and objective. Objectivity is striven after; even subject is objectified by Socrates to "know thyself" to "examine yourself." Analyticity is clean-cut precise, as in Plato's division and collection, in Kant's analysis and synthesis; thinking is systematic, structural and formal, to even separate thinking from worldly mess of irregular changes, "seeing from nowhere" (Thomas Nagel).

Now we walk out of the august halls of the West, and at once Mother Nature breezes our faces, as in Acadian China for millennia. Western flight up for clear principles, summing up things, is replaced by China digging into actuality for unsuspected truths beautiful. Changing perspectives not just dodges life's hurts but turns the hurts into advantages.

Here, all things are alive moving, even in numbers. China envisions things to be somehow one in many different ways, and tells us so in a funny story of Uncle Monkey announcing to monkeys, "Morning, 3 nuts, evening, 4," and monkeys are all furious. "All right, then, morning, 4 nuts, evening, 3," and all monkeys are allhappy (Chuang Tzu 2/38-39).

So, " $3+4$ " is one with " $4+3$ " but both are in two different worlds. Monkeys only know the two-different; Uncle Monkey knows both the one-same and the two-different, and so he can be in one-same moving to other-different. Numbers now move, unheard of in the West. Moving mathematics describes things alive, many in one, one in many; the "in" here is an anathema to the West.

This story, defying Western mathematics, is told by China's master teller of tall tales, Chuang Tzu (399-295 BCE), in his Chapter Two on "logic" of things as equal. This story tells how "tall tales" tell of truth tall and actual, thanks to time flowing from morning to evening, and then evening dawns new day, "day, day, new; again, days new." Philosophy says it is time-logic in numbers moving, a different number-logic from Western where numbers never move, in space-logic; as cultures change from the West to China, our lifeworld shifts from spacelogic to time-logic.

Best it is that we trace China via West-China contrast. The West wants to jump out of the ordinary for exact comprehensive theories to explain everything indifferently. It is the Western mode of research. China keeps digging into common routines for surprising depths alluding to tacit coherence in haphazard changes. It is Chinese research. The West is spatial objective, clear distinct. China sees "space" to feature cosmic time that contains human subjects emerging into history.

The West's logic of spatial surveying is now enriched by China's logic of time daily undergoing. Zeus the supreme with august dike of staid cosmic necessity is turned in China into the whirlwind of elements, functions and perspectives, inter-involving negatively positively, ever alive kaleidoscopic. Every moment ever shifting is eternal absolute, deep on the move.

So, we are ever settled at any moment, while ready to jump out, flying away as birds; "ever” tells of changes, "never say 'never'." Such is the thrilling beauty of contingency. Contingencies situational historical are now no Western headache to struggle to bully through, to try to banish. Contingencies are a pivot in China for persons 
and inter-persons to undergo, to ride on to soar up, inter-thriving socially, world-historically. China is a contingent turnaround of perspective in lifeworld!

Whirling contingencies as the paradigm of research are the mode of its operative expression as well. Here, literature is typified by logic operated by discreet number-units poetized into rhythms, "one, one, one," and then "one, two, one, two," to rhyme into "one, two, three," and so on, and the rhythm goes on. The rhythm of all things makes music of life going, going, and dancing the meaning throbbing on, singing the world.

Meaning comes as our heart beats, and nothing prevents us from dancing with kids, to hop, skip, and jump alive, shouting to the wind. All things bounce together to sing the wild to dance the world. Number-mechanics is poetics of meaning bouncing on ahead. And then night arrives; stars, moon arise. Moonlight sonata flows to put us to restful calm, soft, silent. The babies sleep longest, as night music turns us all into growing babies asleep, alive. Sacred night! Still night! Night then lingers into calm day, and another new day arrives. Such rhythm is our life-song of time homo-cosmic.

It matters not what or how we sing, out of tune, out of melody, or no melody, or whatever. Gregorian Chants sing with Schumann's Abendlied tuneless tuneful. Never mind silly prosody and musical theories, all concocted by snobs, as the dull composer Salieri complains that his students Beethoven and Schubert cannot compose! However sophisticated, all music-criticisms boil down to whether the music is soul-full rumbling deep, or facilely contrived to manipulate. No soul in, no music out. Once ensouled, music erupts. The soul of music is human soul, as soul throbs soul-music of the world.

We sing our souls, we sing soul-music. A baby drones a song, and we all listen enthralled, as grandma is elated, "How pretty you sing, darling! O how pretty you sing!" and grandma means every syllable of her admiration. Songs ensouled can be quite "out of line." "Grandpa, you have hair in your nose.” "O, do I, really! Do you?" "No.” "What do you have?” "Nose wax." Wow! No one disputes this absolutely irresistible conversation as genuine music in all smiles, thanks to the child's soulful sincerity. When sincere, anything comes out is music so pure.

In the West, “doggerel” chants our feelings as “dogs” roaming around, as in China, "hit oil poem 打油詩” is a poem hitting oil so oily slippery, and funny so casual, and we turn so relaxed refreshed that we can now "ride on oil 脂が乘る,” Japan says, to get into the swing of things miles high. If all these common sensibilities and ordinary sayings in so many cultures do not aptly inspire research to chant it on, nothing does. In fact, only such daily soulful singing does real research, anytime anywhere in the world.

The Bible as one pivot of the West is itself made of many cultures. Just "God" alone is holiness and justice for Forsyth, and God almighty warrior against chaos and sea for Levenson. This is one God-culture seen in the Bible. Another perspective takes God as all-love that embraces the rebel son, wailing at his death as father David did, embracing death and hell, and yearns after the rebellious Israelites as he punishes them.

All such visceral love divine is later made ultimate in Jesus Christ. Non-Christians are welcome to take "Jesus" as a stand-in for the Beyond alive. Divine love loves us his dearest beloveds so rebellious, so much so that he dies on the cross for us to judge us to justify us to satisfy his Justice, to grip us tight as death and hell. His hellish love to death on the cross is in turn taken at least in three ways, in three cultures (Aulén, 1948, 2003; Forsyth, 1909; Levenson, 1988; Pope, 1977).

Thus, adult-headaches and kids-laughter, doggerel and music, the Bible, and many others cited in this essay alone are just some of innumerable life-incidents that all show so many different life-cultures colorful crucial. They are all appropriate themes for intercultural researches to elucidate our lifeworld as intercultural.

All this amounts to saying that analytical, objective, and atomistic mode of Western mathematics is now "cured in" as mathematical poetry, in the Classic of Changes and many classics of history, in China. History makes sense, operating in story-thinking that has tacit mathematical bones moving in the telling of tales factual, counterfactual, and "tall," wildly imaginative, alluding to truths tall and common.

Poetry in novels and disputations in China is historically coherent, to deeply shake to shape our feelings in felt living. This poetic mode of thinking and expression, a la time whirling on, includes metaphor in analogy, "as A, so surprising B," allusion, saying A to tacitly point to many things beyond A, and even irony, saying A to tacitly clearly allude to things contrary to A.

"Is this thinking-mode, itself whirling and contingent?" Yes, it is, while its contingency is firmly coherent, reflecting life as reasonable beyond simple one-track logic. "The heart has its reasons, which reason does not know.” This famous quip of Pascal's could be uttered by China to the West, to seek joining hands to bring each to live in the other, to together explore actuality, doing co-researches into actual world that is both feeling rea- 
sonable and rationally felt (Pascal, 2014).

Emotion brings out motions-e-motion - one into another of the felt souls of all beings, persons and trees, stones and brooks, fields and skies friendly and terrible. All this while, reason gently combs through their complexities to bundle them into snug coherence, orderly all around. Such is the Chinese praxis of the lifeworld personal, interpersonal, inter-species, and cosmic intercultural.

Here, mathematical coherence exists but quite pulverized to an unrecognizable extreme. Here, "P implies Q" can often turn "Q implies P" as woe breeds weal as weal breeds woe, as Lao Tzu 58 insists and as life actually goes. The entire logical implicative system can turn backward as in Mo Rhetoric 墨辯, as "parallel reading of sentences." As a result, paradoxes and non-sequiturs abound in Taoism, freely used to elucidate the sense of the common in Confucianism. This elucidation is China's research.

Against all this, arises the no-nonsense Realpolitik of Legalism 法家, embodied in the almighty rulership, all hidden legally socially. Thus it is that philosophical situation in China is alive in turmoil, rife with possibilities and counter-possibilities imaginable and unimaginable. All this orderly mess reflects the actual life-situation through world historical ages. Mathematical logic is now the logic of storytelling flexuous and free, fascinating and surprising.

"Wow! All such stuff sounds so abstract, separate and far away from actual life! Is all this practical China?" All right, then, here is how concretely the logic of time in China goes on, in a timely way. We are no debris helplessly floating in time stream, nor are we to violently cut into the time-flow, trying to stop the river, or even push the river this way or that.

Instead, we ride the crest of wave of the situation, as we steer into our grain into the grain of shifting situations. Our stratagem flexes with the flow to take advantage of its propensity (Jullien, 1999). China's 戰國策 Warring States Stratagems has stories of rhetoricians persuading this state, and then that state its enemy. It takes soft yielding ingenuity, sinuously flowing to follow the deathly streams of situational tyranny, so much so that this brutal tiger-force of the situation comes to even fawn on us the tiger-tamer (Chuang Tzu 2/50-52).

It takes a thief to tame a thief; only poison detoxifies poison. We ride on the trend now dragon-soar, now snake-slither, as in timely measure-mathematics! —-we swim in the gentle current, and steer us in the steep cataract (Chuang Tzu 20/6-7, 19/49-51). "How do we do research in this situation?” We do research here by experience to get sensitive knack to steer us in the flow, quite risky. The knack is the logic of time timing itself in timely way. It is the logic of living. A concrete example comes to mind.

We see today how, in order to cut down on senseless gun-violence in USA, people do not directly cut into the powerful National Rifle Association (NRA). Now, never mind probing why NRA so irrational is so powerful. We need not probe the origin of Hitlerian tyranny in order to resolve the problem so tense deathly, as Buddha counsels us. We have been using electricity not knowing what it is. Probing what, why, and wherefrom of contingency is one thing; riding the crest of its wave is quite another. China wants the riding, not the cause.

People in America swim around NRA's powerful opposition to gun-safety policies, with massive petitions to the Congress, publicizing the names of senators bribed by NRA, campaigning with many new organizations such as Mayors against Illegal Gun Violence. President Obama is one crucial push in this "people overwhelm" stratagem. Huge currents, for and against gun violence, are making huge waves today. USA people are dealing with gun-violence and NRA Chinese way. Such is one life-research on pressing life-dangers of daily gun-violence in USA.

It is now time to sum up China, with gusto. China is present at the stark presence of things here now, anywhere anytime. Simple presence cuts through things' complexity, in children's gutsy honest shout, "He has no clothes!" And the child does not care if that "he" is an emperor! Honesty is simple straight, and sharp, to the point.

Free simplicity through complex things can go this way and that, now producing analogy and metaphor, now alluding pointing, now giggling ironic non-sequitur, playing logic backward and forward, devil-may-care. This playful cut-through is almighty, enabling us to ride the crest of wave of uncertain contingencies so risky, timely opportune. It is China's logic of time tuned to heartbeats of things, making sense all common, ever changing, deep and alive. Its time-logic soulfully sings the world.

\subsection{West-China Interculture}

We thus see that each has its strengths and weaknesses, and that the strengths of one happen to parallel the 
weaknesses of the other. Naturally, each does well to learn from the other to breathe in the other, to inter-complement to make our human research relevant situational. Here we need discernment of philosophy observant.

China is moving intensive but tends to be mysterious ineffective, and tends to fall in pedantry mincing words playing with empty sentences, to be locked in its tiresome tradition, turning the exciting past into slogans. The West is effective future-oriented, to turn us vacuous, individualistic, lonesome in ennui, as its impersonal engine of efficiency bulldozes everything to destroy nature with us all.

Western efficiency must then deepen to personalize to turn things co-alive with us, as our technological hand gestures the feel of milieu cosmic in the depths of the primordial past of things, whose "tree rings" of ages are appreciated. China's literary flourishes must bite into life's nitty-gritty; feelings must dig laboriously ahead to manage to change our milieu, trained in the sensitive knack swimming in things unpredictable.

China and the West must thus inter-melt, not inter-melting away their geniuses. Their respective strengths can/must inter-stimulate to inter-enhance, as the West looks outside to China, as China extends hands to the West. Our common human research must thus turn intercultural, all kid-fresh, jumping alive, inter-stimulating world over.

Western clarity must be sensitized; Chinese sensibility must be clarified. The West's analysis must not be Platonic division but organically interconnected, in process. Western synthesis must not be Platonic collection but feeling-intensive. China's sensitivity is not to be roaming haphazard, but spontaneous subtle, hitting the point by alluding, tacitly logical. China's intensity is to turn sensible seasonal, coherent, soaring.

No mathematical logic of the West can puzzle out Kekule's discovery of benzene formula launching organic chemistry, much less chart its route. Discovery is the soul of research, and "logic of discovery" cannot be composed, as logic surveys what already is the case, and discovery initiates the case (Wu, 2001). Thus no logic can direct research, as logic retrospectively cleans up the mess after discovery. Research as discovery ventures out into unknowns, and no unknown is handled by retrospective logic.

Of course mathematics itself does make progress, but its process of progress cannot be handled by mathematics. Scientific progress in the West is made despite a lack of the directive of Western mathematics, not because of it. In fact, mathematical logic is a set granite-like structure, gradually revealing itself as such to human mind's inspection, which is not mathematics. Parmenides is correct in announcing motion as impossible, but then his announcement is made impossible by his logic. "No movement" is death to research that by nature moves.

This is not to say that Western mathematics is useless for research, but that it is a tool to clean up to clarify the results precious and messy. Such tool's neat serviceability to research should yet never be mesmerized to trap research immobile; the baby dies when over-cleaned, though in need of cleaning to jump forward alive. Research needs Western mathematics to proceed; its proceeding must never be beholden to mathematics. There is no "logic of discovery" though discovery is found logical later.

Thus the West and China must inter-flow free, distinct, concrete, to shift growing as kids. Such flow is to hit right unawares in life-vigor overflowing intercultural. Western mathematics now turns reasonable poetic, as Chinese poetry is now number-apt, sharp to the point. Our research flutters around as butterfly, orderly mathematically.

But beware. Interculture is inter-local; perspectives and thinking-modes can be critically inter-learned interenriched, only by deeply knowing specific local perspectives and thinking-modes, and specific awareness comes by contrasting with other cultures, to inter-learn. Local as global is intercultural; self and other interdepend to grow into itself. We have dug into respective geniuses of two specific cultures, the West and China in their contrast. Our results can be extrapolated to apply to other intercultural engagements otherwise confusingly unlimited.

Even "togetherness," at the base of interculture, is itself different as cultures differ, crying out to be researched intercultural. Let us take just two examples of togetherness, populism versus democracy, and communalism Buddhist, Christian, and communistic. Togetherness is people-centered, interpreted in China as "populism 民本 思潮” Heaven-sanctioned, different from Western “democracy.” Heaven sees as its people see, hears as its people hear, and any ruler who overrides people's needed welfare for his selfish enrichment would die by popular “raising justice 起義," bloody revolution.

In contrast, people-supreme in the West is politically crafted, by Locke, Hobbes, and Rousseau, as peoplepower, “democracy,” where sovereign people delegate management of social affairs to governors people-elected, to replace divine right of kings. Democracy is a political arrangement to balance power conflict between people governed and government governing them, irrelevant to populist ethos of China. Populist ethos and democratic 
arrangement need be researched into intercultural inter-enrichment.

Our second example of people-supreme is "communalism” yearned after all over. But its understanding differs as cultures differ. Buddhism embraces mutual help on the basis of Buddhist karuna, mercy for the sentient, to craft its concrete facilitations. Christianity promotes communality as agape, sheer love of God in Christ freely dying and rising again for all humans. Love feasts and love deeds as Christ are encouraged.

And then, Marx proposed Communism for poor workers' welfare, for human happiness is based on economic equality between boss and workers. Communism itself can be of three kinds, an ideal of social equality, an ism based on economic origin of human happiness, and polities Russian, Cuban, and Chinese. In all, intercultural togetherness is thus local and cultural. But even carefully based on locality, intercultural research still has two risks, to which we now turn.

\subsection{Daunting Interculture and Collapse of Interculture}

Interculture, as a daring adventure in radical togetherness worldwide, bristles with mortal risks; two are cited here, how we [a] are spontaneously daunted at interculture, and then, [b] how interculture can collapse anywhere, together with their resolutions, to negatively tighten this essay on research based on and soaring to interculture, and description and tightening is philosophy in sensitive scrutiny. So this section is a grand summation of the whole essay, "research: philosophy intercultural."

[a] To begin, interculture is "living with," with beloved or with difference, and "with" is often pain in two ways. One, "Living apart is pain; died separated is pain," said Buddha, assuming that being with the beloved is joy. My loved one is my joy, and so "living apart is pain; died separated is pain." But things are more complex.

Being with my beloved is also often pain of frustration, sharing joys not responded, silence over my disappointment with beloved. And I cannot "live apart" from her as she is my beloved on whom I depend to live. I am alone with my dear body, my dear writing, and with my Mother Nature. "I am here. Isn't it more than enough?” says she. "Abide in me,” her silence whispers. So help me, Mama!

Two, interculture lives with differences uncomfortable. "My culture, right or wrong!" lives with "birds of a feature," breathing my own cultural air. "You" smell odd, so you need not even talk to me. I don't like to be told that difference is my enrichment by learning from "you," that difference is good medicine tasting bitter.

Thus interculture has these two obstacles of being even with "beloved you" and with "different you." Learning across cultural line is my tough discipline. "Pain of love and difference is your certificate to interculture, your ticket to global togetherness on which we live. Beware, my dear intercultural researcher," says philosopher sober, sensitive, watching.

Moreover, research intercultural is full of mistakes, taking things amiss in our blazing of trails in virgin forests of things vast wild. And then, strangely, our research, always mistaken, also comes without mistake, as research continues to search for things new, alternatives to roads taken amiss. Thus our persistent pursuit-researchcomposes "research" mistake-filled and mistake-free, full of mistakes without mistake, in trial and error with no error, losing our way to find the right tool to find the right way.

Such a paradoxical nature of research originates in the fact that research is ever on the move; research stops and tarries, tarries to look around to orient the researcher, only to go ahead, as its looking-around is in perpetual process of correcting-itself. After all, research is search-around by looking around to search around. Such is world-happening that world-corrects to compose our world-research, our mode of living on, our historic way of life.

[b] Now here is collapse of research and how to get through it. In our research as search-around, trying this cultural way and then that, we can easily get lost in the middle of vast cultural nowhere. We go far away, and cry with our fellow Zulu, "O mother, I am lost” (Buber, 2000)! I must now point to a way out, my body, as sure as I myself got lost. I suggest to my body that I follow what I need what I want. This is my "body thinking," not just as my physical body needs but as my whole gut-level body groping in bodily vista, in my bodily vision. This is the way of primal research.

Doing my body thinking, I soon find my fellow human beings doing their own body thinking. We can show and tell, to compare body-notes. This is story thinking. "Story makes the world" as wise historic American Indians tell us (Frey, 1995); many stories make many worlds. This story thinking thus composes our interculture again, in a history way, but this time from the motherly womb of "getting lost" with our Zulu fellow beings. We are all deeply body-rooted in our motherly traditions shared story-way, bodily way. 
Another guide out of our getting lost, no less powerful efficient, is children, the counterpart of "O mother! I am lost.” What mother has no child? Mother gives birth to children, born-researchers with insatiable wonder in untiring curiosity in ubiquitous search, so they inevitably go intercultural research. Besides, children have no enemy; every child is every other child's playmate. "Every” here poignantly indicates interculture. Its poignancy can be shown by a joke.

A cruel joke has it that President Ma of Taiwan fell into a ditch. He looked up and saw three children walk by. He hailed them for help to pull him out, promising them with whatever gift they want. One says he wants a baseball glove, another a bike. A third asks for a wheelchair. Puzzled at such a request from a healthy walking child, Ma asked why. The child said if his father knows he rescued Ma, father would break his leg.

Baseball glove and bike both expensive indicate their love to play. The third one comes out poignant; that third child knows Ma is hated by his father, and still wants to pull Ma out, even at the potential price of a broken leg. His indomitable friendship wholly without enmity is poignantly obvious. This pan-friendship forebodes quite well for global interculture. Children are born intercultural researchers to pull us adults out of our discriminatory ditch of getting lost in intercultural research.

Once we follow this child-way bodily-way, we can now never get lost. We can now go out doing research together inter-culturally, in our vast misty Mother Nature, for we cannot get lost in our Mother of all mothers with her children. We can each freely sigh in our research, "O mother, I am alive in you, my Mother Nature, with my child sisters and brothers, vibrant bones of my bones!" "If this is not research intercultural, even by getting lost, and by getting broken legs, nothing is," philosophy softly whispers, in bodily sincerity, in thoughtful kid-sensitivity.

All in all, such is how we have overcome the fear of difference and even taken advantage of the chance of getting lost in the bewildering thicket of interculture, to strengthen to promote interculture worldwide at all cost including broken leges. We can now be on our confident way to research intercultural, with all researchers in all cultures all over the world in all our spontaneity, innate and kid-friendly.

At this final point, allow me to indulge in meditations of an ultimate sort. I deeply feel in my soul that this life is just a door to the next stage all-joy all-tearless, and I don't even need to die to realize this world as my door (Alexander, 2012), back and forth Janus-way. This is Alexander's confessional report on what he experiencedhow, after seven days of coma, given up by his doctors, he came back alive. Can you imagine how all treasures of cultural legacies of this world are all an outright gift of the great dead, poured down from their other world? All excellences of our vast cultural heritage we enjoy every second, including our languages and our thinkingmodes, are excellences carved out by our dear dead giants, almost all unsung. We the living people then slowly learn to add a bit here, and a bit there, all pitifully puny, before we also die to join them soon.

Conversely, every despairing rustle in breeze of our life-sincerity, and every shout of gutsy kid in joy and our every wailing in sorrow, resonate with that other world and are deeply appreciated there beyond this world. The Christian Gospel picks some of them. For example, Luke 7: 37-50 tells of a sinner lady, so lonely so despised by all people around, stood behind Jesus, weeping wetting his feet, then wiped them with her hair, kissed them and anointed them with fragrant oil. She deeply moves Heaven in Jesus, as she deeply moves me. We three, she, Jesus, and I, mutually resonate in the visceral depths to the heaven.

It is sheer insanity to brush aside as illusory these soul-chants deep cosmic, here and beyond, back and forth, too filled with pathos to be contrived, too heartfelt to falsify. But Marxism does take all this as an illusion, and the priests and Pharisees even bribed off Roman soldiers' eyewitness reports of Jesus' soulful breakthrough in this life toward life beyond (Matthew 28: 2-4, 11-15). That sinner lady came defying popular disdain, and got recorded in the Gospel of Luke. On my small part, I won't be concerned with daily despairs while alive any more; I rejoice that all my sorrows resounds all, here and beyond here.

"What does all this have to do with research intercultural?" Quite a bit, I would say. This fact that this life is a Janus door to the next life is an existential rationale for claiming that our human research is a Janus door to the future of many brave new worlds here and beyond here now. I would not be surprised if our researches rumble the other world beyond as they do this world. Our research leads to envision the world far ahead beyond here now.

“Great Ways go unhindered as the public shares all under heaven 大道之行也天下為公!” an ancient Chinese classic famously chanted. Such Utopia has been persistently yearned and pursued after, and has always been knocked off by private ownership of properties. All types of communalism have been tried in history, such as Communism that despises my above sentiment beyond this world, unaware that the Communists themselves are 
the foretaste of our undying hope for the beyond-miseries of this world.

Death, into which not a penny can be moved, ushers our life all-free into such heavenly Bliss, and children and artistic beauties allow us a glimpse into this ultimate Bliss in this world. Death, children, and beautiful arts are three great mysteries envisaging incorruptible joys all over this intercultural world with the world beyond. Heavenly Jesus heartily accepted that sinner lady's heartfelt tear-full self-giving, despite public disdain. All our good-willed deeds soured or slighted, all our slightest gestures forgotten even by us for the least of our brethren, are all meticulously cherished, and lustily chanted by the tearful Jesus beyond this world, mumbling "You did it to me.” (Matthew 25:40) Our research is one of them; Jesus is smiling.

This is the ultimate justification of our research and the ultimate theme of our research intercultural toward cosmopolitan concord. Even the casual common wind is lovingly researched by Chuang Tzu into fabulous poetry that equalizes thinking and things (as his second chapter). This poetry reaches the farthest reaches of Heaven and Earth and beyond, out of this world. All this while, sensitized philosophy is gently whispering to us avid researchers, "Shall we bravely proceed with our research intercultural between Heaven and Earth, in our daring hope of cosmopolitanism even beyond this world?”

\section{References}

Alexander, E. (2012). Proof of Heaven: A Neurosurgeon's Journey into the Afterlife. New York: Simon \& Schuster.

Andersen, C. (2006). The Complete Hans Christian Andersen Fairy Tales. New York: Random House.

Apel, W. (1972). Harvard Dictionary of Music (2nd ed.). Cambridge, MA: Harvard University Press.

Asimov, I. (1964). Asimov's Biographical Encyclopedia of Science and Technology. Garden City, NY: Doubleday.

Aulén, G. (1948). The Faith of the Christian Church. Philadelphia, PA: Muhlenberg Press.

Aulén, G. (2003). Christus Victor: An Historical Study of the Three Main Types of the Idea of Atonement (Translated by A. G. Herbert). Eugene, OR: Wipf \& Stock Publishers.

Blake, W., Erdman, D. V., Bloom, H., \& Golding, W. (1997). The Complete Poetry \& Prose of William Blake. New York: Doubleday.

Buber, M. (2000). I and Thou. New York: Scribner Classics.

Forsyth, P. T. (1902). The Cruciality of the Cross. London: Hodder and Stoughton.

Frey, R. (Ed.) (1995). Stories That Make the World: Oral Literature of the Peoples of the Inland Northwest. Norman: University of Oklahoma Press.

Gray, G. (1970). Understanding Violence Philosophically and Other Essays. NewYork: Harper \& Row.

Howatson, H. C. (Ed.) (1991). The Oxford companion to classical literature (2nd ed.). New York: Oxford University Press. Jullien, F. (1999). The Propensity of Things: Toward a History of Efficacy in China. New York: Zone Books.

Kipling, R. (1940). Rudyard Kipling’s Verse: Definitive Edition. Garden City, NY: Doubleday.

Kuhn, T. S. (1993). The Structure of Scientific Revolution. Chicago, IL: University of Chicago Press.

Laszlo, E. (1993). The Multicultural Planet: The Report of a UNESCO International Expert Group. Oxford: One World.

Levenson, J. D. (1988). Creation and the Persistence of Evil. New York: Harper \& Row.

Levinas, E., \& Lingis, A. (1969). Totality and Infinity: An Essay on Exteriority. Pittsburgh, PA: Duquesne University Press. Murphy, B. (2008). Benét’s Reader's Encyclopedia (5th ed.). New York: Harper \& Row.

Oxford University Press (2001). Oxford English Dictionary (2nd ed.). New York: Oxford University Press.

Pascal, B. (2014). Pascal’s Pensées. New York: E. P. Dutton.

Pope, M. (1977). Song of Songs. Anchor Bible, New York: Doubleday.

Taylor, J. B. (2009). My Stroke of Insight: A Brain Scientist’s Personal Journey. New York: Penguin Books.

Whitehead, A. N. (1978). Process and Reality: An Essay in Cosmology (Corrected Edition). New York: The Free Press.

Wu, K.-M. (2001). On Metaphoring: A Cultural Hermeneutic. Leiden: Brill.

Wu, K.-M. (2008). The I-Milieu: Its Implications for Culture and Thinking. Journal of World Religions, No. 11, 1-120. 
Scientific Research Publishing (SCIRP) is one of the largest Open Access journal publishers. It is currently publishing more than 200 open access, online, peer-reviewed journals covering a wide range of academic disciplines. SCIRP serves the worldwide academic communities and contributes to the progress and application of science with its publication.

Other selected journals from SCIRP are listed as below. Submit your manuscript to us via either submit@scirp.org or Online Submission Portal.
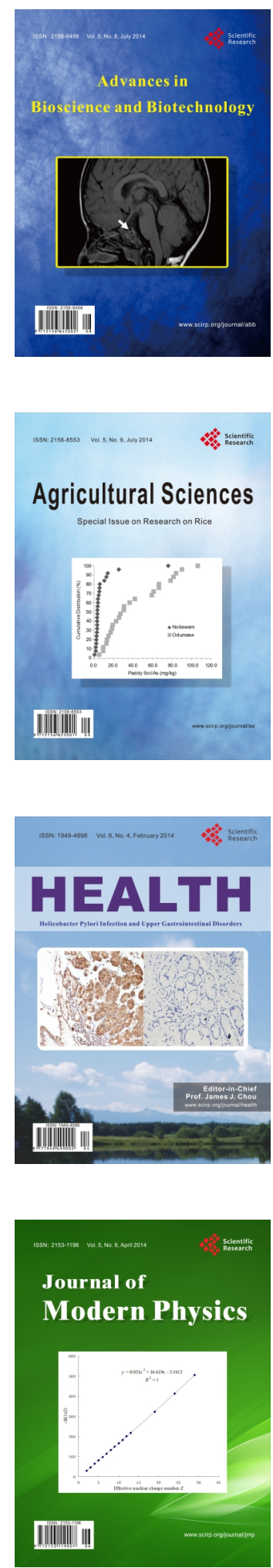
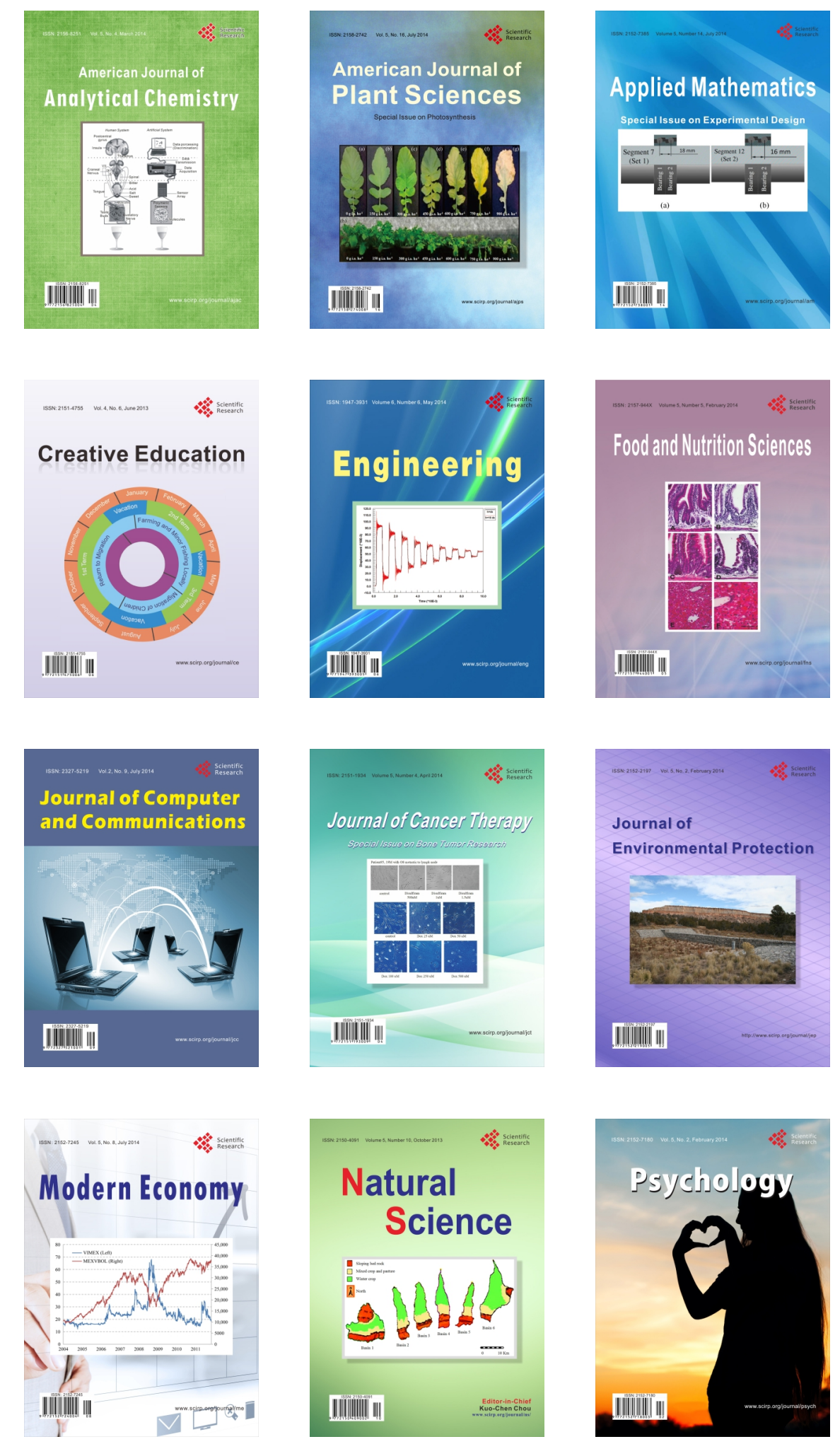